\title{
Suitability of pre-perforated post-reinforced baked clay beam panels for low cost housing
}

\author{
Abdul Aziz Ansari ${ }^{1, ~ *, ~ N a d e e m-u l-K a r i m ~ B h a t t i ~}{ }^{1}$, Muhammad Aslam Bhutto ${ }^{2}$ \\ ${ }^{1}$ Department of Civil Engineering, Quaid-e-Awam University College of Engineering Science \& Technolog, Larkano, Pakistan \\ ${ }^{2}$ Ph.D. Scholar, School of Built Environment Heriot-Watt University Edinburgh, United Kingdom EH14 4AS
}

\section{Email address:}

dransari@quest.edu.pk(A. A. Ansari), Nadeemkarim94@gmail.com(N. Bhatti)

\section{To cite this article:}

Abdul Aziz Ansari, Nadeem-ul-Karim Bhatti, Muhammad Aslam Bhutto. Suitability of Pre-Perforated Post-Reinforced Baked Clay Beam Panels for Low Cost Housing. American Journal of Civil Engineering. Vol. 1, No. 1, 2013, pp. 6-15.

doi: 10.11648/j.ajce.20130101.12

\begin{abstract}
Systematic research is being carried out since last more than one decade to prove the validity, method and materials for construction of locally available alternatives as low-cast systems for the sake of swift erection of buildings at relatively affordable cast of construction, where the pre-cast post-reinforced panels are used for erection of buildings without sacrificing the strength and durability of the buildings. One of the most universally available materials of construction since immemorial times is the earth itself, particularly in the plain areas (Pakistan) where the soil is fertile and the availability of best combination of clay and sand is not problematic. In this paper the authors present the details of systematic research which has been carried out to prove that if pre-perforated post-reinforced baked clay beams are employed for pre-cast construction, the economy could be achieved by up to $30 \%$ without sacrificing strength, durability and stability of construction. Initially soil was dug from 25 sites at a depth of $4 \mathrm{ft}$. Their physical properties were determined. The presence of various salts and their proportion were also found. A very large number of cubes were cast with clay as major material and percentage of pit-sand (silica) as major parameter. The results of preliminary study in terms of shrinkage, specific gravity, crushing strength, tensile strength, poison's ratio, and modulus of elasticity of baked clay specimen and the best possible combination of clay and pit-sand were obtained. The material was then compacted by applying compression. Fifty two beams with $70 \%$ clay and $30 \%$ pit-sand, 20 percent water and $4.5 \mathrm{~N} / \mathrm{mm}^{2}$ compacting force were cast, dried, baked, post-reinforced, grouted with cement and hill-sand slurry with the ratio of 1:1 for proper bond between steel bars and surrounding baked clay were tested with point load, UDL and various boundary conditions including roller support, plate support and complete end-fixity. Full details are presented in the following section.
\end{abstract}

Keywords: Compaction, Baked Clay, Strength, Durability, Ease of Construction

\section{Introduction}

It is a well-established fact that clay has remained in use as universally available material of construction since thousands of years. When technology was not available, people resorted to clay, both sundried and baked in the form of bricks to construct the walls and wooden logs as support to construct houses as ceiling over their heads to avoid the exposure to the heat of summer and the cold of winter. Even today in advanced countries like Britain millions of houses are constructed with bricks as major material. However, due to ever increasing cost of construction has laid to various experimental studies for construction of relatively cheaper houses by using materials which are locally available in the vicinity. Although research has been carried out over past several generations on RCC work which makes use of industrially produced steel bars, hill sand and aggregate as major materials of construction and surprisingly things have come to such a pass that even buildings as high as 125 stories are not beyond the reach of human race. In the affluent countries like Dubai, not to speak of industrially advanced countries like USA, these buildings are the pride of mankind at present times. With all those facts and figures in the mind, the idea was conceived to construct pre-perforated post-reinforced baked clay panels of structural members which are relatively cheaper and affordable by the masses of developing countries.

The modern tendency is towards the use of reinforced cement concrete for the construction of multistory 
buildings consisting of structural frames and slabs. The cost of construction and the time of completion are drastically reduced, if instead of casting the structural member's insitu, factory made pre-cast panels are transported and used for the erection of buildings. It is more beneficial if the buildings are to be constructed on mass scale and the variation of sizes is kept to a minimum. The plains of our country (Pakistan) where the soil is alluvial and there is the dearth of fine as well as coarse aggregate, almost every single item i.e. cement, steel bars, fine \& coarse aggregate are to be transported from very long distances. Being very heavy materials substantial amounts are to be paid as their cost of transportation. Thus it is beyond the reach of a common man to opt for RCC construction. The universally available materials of construction in the plain areas are clay and pit sand. At present burnt clay bricks are being used for masonry construction and for lintels to span over small openings like those of doors and windows.

If instead of bricks we can produce baked clay panels of beams, columns, slabs and footing etc. which are pre-perforated so that the reinforcement bars could later be placed and grouted with proper bond and if we can attain the strength properties resembling to those of cement concrete and if a reasonably good margin of reduction of prices could be achieved, then the dream of low-cost housing in its real sense could come true.

Let it be known that the senior author has remained engaged in research for last more than twenty years[1-15]. One of the aspects that are presented here is a new technology which pertains about bringing the well-known material i.e. clay for construction of houses resembling to those as RCC. Several options are available but the modern tendency is towards the construction of the houses which are sufficiently strong, durable and elegant. It may be noted with satisfaction that clay with its certain component of sand as additive is not inferior material but only because it did not receive proper attention so far. Clay is a fine-grained, natural firm earthy material that becomes plastic when wet at appropriate water content, hardens when dry and gains strength like a permanent solid when heated intensively, consisting of hydrated silicates of aluminum[16]. Natural, non-toxic, healing, easily available, recyclable, low embodied energy, a pleasure to work with, soft \& soothing, limitless creative possibilities are some of the properties of clay. Some people may describe it primitive, inferior and dirty. Depending on the contents of the soil, clay can appear in various colours, from a dull gray to a deep orange-red. The formation of clay from rock is a most common event, taking place daily everywhere in the world. Clay consists of soil particles, the diameters of which are less than 0.005 $\mathrm{mm}[17]$.

\section{Research Significance}

Basically in third world countries the purchasing power of common man is very much limited. Therefore to construct a house using reinforced concrete is not within the reach of majority. However, if local materials like clay together with pit-sand (silica) can be utilized to construct the house with the structural properties resembling to those of concrete, the low-cost housing objective could be achieved without sacrificing the elegance, durability and structural soundness. Therefore attempts have been made to study the fundamental structural properties as well as flexural and shear behaviour of beams manufactured from baked clay with post-reinforcement using grouting as bonding material consisting of fine hill sand and cement sullery so that there could be mass scale production of pre-cast panels for rapid erection of structural frames along with brick masonry as dividing walls so that dream of low-cost housing could come true.

\section{Plan of Research}

a In all, twenty five sites were selected for determination of various properties like salinity and its effects on overall performance of baked clay panels.

b To conduct experimental study on clay specimens for the best composition in terms of sand to clay ratio for best possible strength properties.

c To test the baked clay specimens to determine the required intensity of pre-compression for compaction to attain the strength properties of baked clay specimens comparable to those of concrete (grade-20).

d To determine optimum water content which must be mixed with clay at the time of moulding? This could give reasonable workability and strength without requiring enormous force for compaction.

e To determine modulus of rupture of baked clay beams without reinforcement.

f To study the behaviour of rectangular as well as I-section beams of baked clay, which are moulded, dried and baked with holes (pre-perforated) at appropriate places and post-reinforced with steel bars by using cement slurry for grouting.

\section{Methodology}

Initially $\mathrm{pH}$ value, Electric Conductivity, Exchangeable Sodium and Gypsum, Total salts content in solution (PPM), Moisture Contents, Specific Gravity, Liquid Limit, Plastic Limit, Flow Index, Liquidity Index, Plasticity Index, Consistency Index, Toughness Index, Density of wet and dry soil are to obtained from twenty five different sites. Preliminary studies are performed in terms of shrinkage, specific gravity, compressive strength, tensile strength, Poisson's ratio and modulus of elasticity of baked clay specimens consisting of hundreds of specimens including cubes, cylinders and briquettes. The major parameter is clay and pit-sand ratio. A large number of baked clay specimens are compacted by applying compacting force of $6 \mathrm{~N} / \mathrm{mm}^{2}$ to improve the structural properties. Substantial equipment and 
testing arrangements required are also fabricated. Stiff steel moulds are fabricated for casting the models of beam panels. The design of these moulds is accomplished on the basis of stress analysis performed by using computer software using Finite Element Analysis. The analysis is particularly aimed at finding the lateral deformation of the mould due to applied compression for compaction. Elastic out-ward displacement is determined in order to ensure that bulging of the beam resulting in the expansion of the sections could not occur. Special arrangement for applying the pre-compression manually (so that density could be improved and compaction to the desired degree could be achieved), is designed.

\section{Equipments \& Machinery}

Since no attempt was made ever before to cast and test the clay beams. The large number of pieces of devices and equipments were not available in the market so could not be purchased. Therefore, all such items were devised according to specific needs of various operations. They were designed and fabricated within the premises of QUEST, Laboratories. However, the standard equipments whatever were already available in the structures laboratory were employed. The detail of all the devices, equipment and machinery are presented in the following sections.

- Clay Drying Oven

- Pulverizer

- Pan Mixture

- Stiff Steel Mould

- Restraining System of Mould

- Compaction System

- Puller System

- Beam drying System

- Trolley

- Platform Lift

- Thermocouple

- Grouting System

- Curing Tub

- Mobile Lift

- Pre-Compression System

- Two Point load Attachment

- End Fixity Attachment

-Baked Clay Specimens Cutter

- Beam handling System

\section{Experimental Campaign}

It may be re-iterated here that the total research work has been divided into two series i.e. Preliminary Test Series and Main Test Series. The latter is further sub-divided into five phases. The effective span of all the beams was $1670 \mathrm{~mm}$ (65.75 inch). Apart from baked clay beams four concrete beams were also cast, cured and tested for the sake of comparison. Mixing of materials depended upon best proportions of clay and pit-sand. Total water content as percentage in terms of dry material was maintained at about 18 to 20 percent on the basis of the results pertaining to workability and strength to be achieved. The clay was obtained from various sources at a depth of $1220 \mathrm{~mm}(4 \mathrm{ft})$ from the ground level. It was dried at a temperature of 105 ${ }^{\mathrm{O}} \mathrm{C}$ for 24 hours. The clay was then pulverized for micro-fining it. Then as per previous research conducted by the senior author[2] $30 \%$ of pit-sand, was mixed. Mixing of the materials and the water was done with the electrically operated Pan mixer. Mixing was done for approximately 10 minutes for each batch. After delivery of the material in the mould, compressive force was applied and measured with the help of electric load cells and digital display amplifier system. Compression was applied by tightening the wings nuts as shown in Fig: $1 \& 2$.

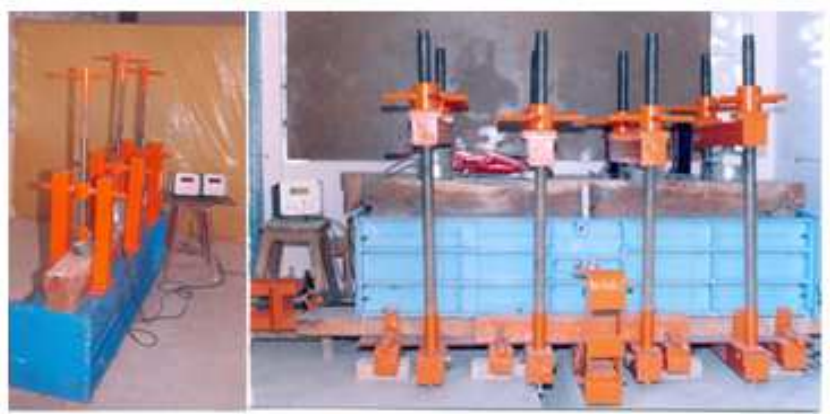

Figure 1\&2. Compaction system of baked clay beam

Whereas the strength of concrete depends upon the proper mix design for a certain required characteristic strength, the compression force for compaction is the major factor to achieve the required strength of baked clay. For concrete water: cement ratio, compaction and curing are the major factors. However, for baked clay water content is the most important factor which should be maintained at the minimum possible level (optimum moisture content) to reduce the void ratio and increase the density with considerable compaction force. Several impediments and hurdles were faced during process. For example enormous shrinkage occurred during drying which caused cracking of the beams rendering them useless.

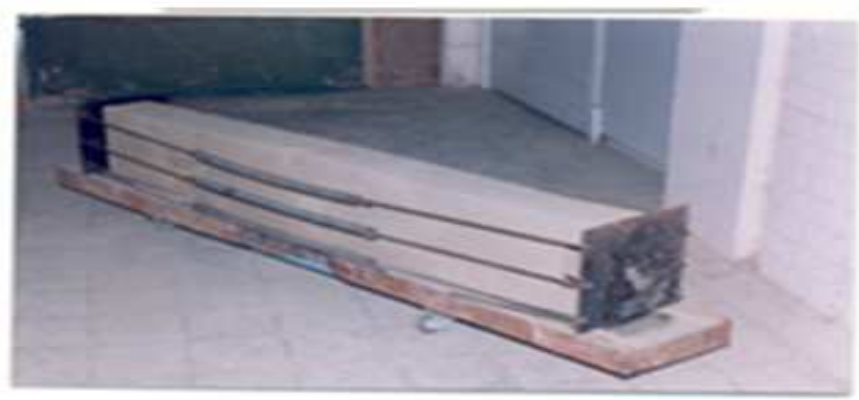

Figure 3. System used to avoid the cracking in the clay beams due to shrinkage

The drying under the shade without exposure to sunshine with a thin plastic wrapper solved the problem. Special 
scheme was resorted to by providing a heavy wooden plank fitted with a very smooth surfaced metallic sheet properly oiled to support the beam specimen at the bottom during its drying period; so that shrinkage and consequent deformation (i.e. shortening of the beam) did not cause any cracking. However, a system of slight compression with the help of springs was also devised and used as shown in Fig 3.

It must be mentioned here that the beams cast, dried, baked and tested during this experimental investigation were $150 \mathrm{~mm}$ (6 inches) wide $300 \mathrm{~mm}$ (12 inches) deep and 1950 $\mathrm{mm}(6.5 \mathrm{ft})$ long initially but were reduced in length by 100 $\mathrm{mm}$ (4 inches), breadth decreased by $7.2 \mathrm{~mm}$ ( 0.3 inches) while the depth showed a shrinkage of $14.3 \mathrm{~mm}$ (0.6 inches). The thickness of flange of I-section was $50 \mathrm{~mm}$ and that of web $100 \mathrm{~mm}$. The load was applied gradually in small increments of $4.6 \mathrm{kN}$ each. After drying for sufficient time under the shade the beams were exposed to sunshine to exclude as much moisture as possible which was trapped deep inside them. A few rectangular and I-section beams before baking are shown in Fig. 4 \& 5 .

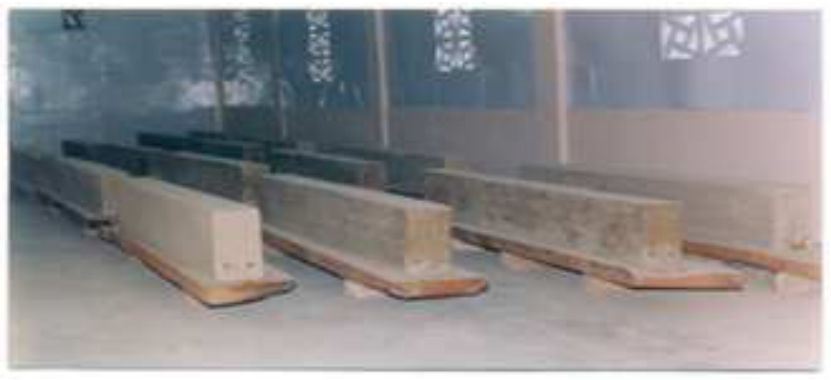

Figure 4. Rectangular clay beam before baking

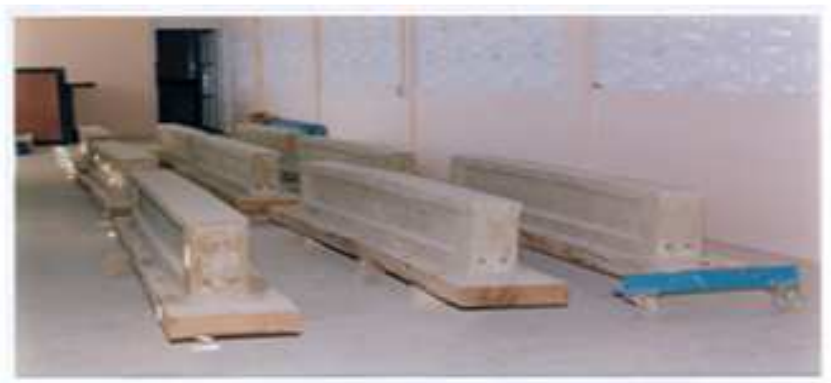

Figure 5. I-section clay beam before baking

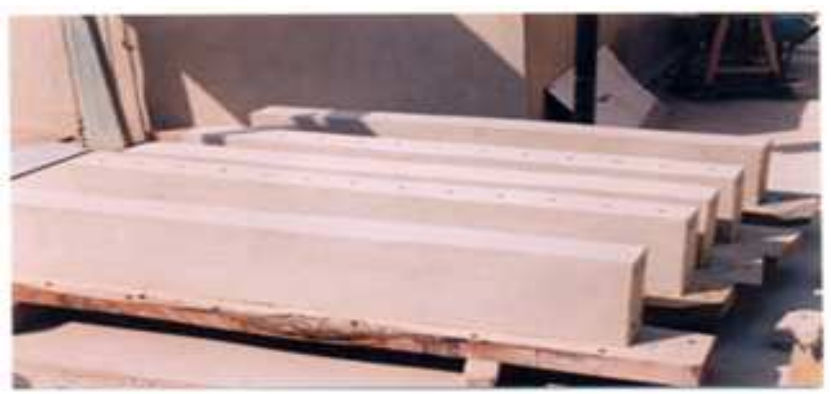

Figure 6. Clay beam after baking

The beams were then placed in the Kiln, where the temperature was measured with the help of Thermo-Couples.
The temperature and time periods were selected after trying a large number of temperature and duration combinations to achieve the best possible results because the thickness of beams is obviously much more than bricks and therefore the complete baking of the beams could be possible only on the basis of experimental investigation. A few beams after baking but before testing are exhibited in Fig. 6 .

The beams were pre-perforated near the bottom with two holes of one inch diameter for placement of tensile reinforcement. However, a few beams were reinforced both at top and bottom hence there were two holes near top and two near the bottom in these beams. A few beams contained vertical holes at 6 inch centre to centre for shear reinforcement. The steel bars of $3 / 8 ", 1 / 2 "$ and $5 / 8$ inch diameter were used as longitudinal reinforcement. A puller shown in Fig 7, was manufactured to pull out the steel shafts from the beams after their casting.

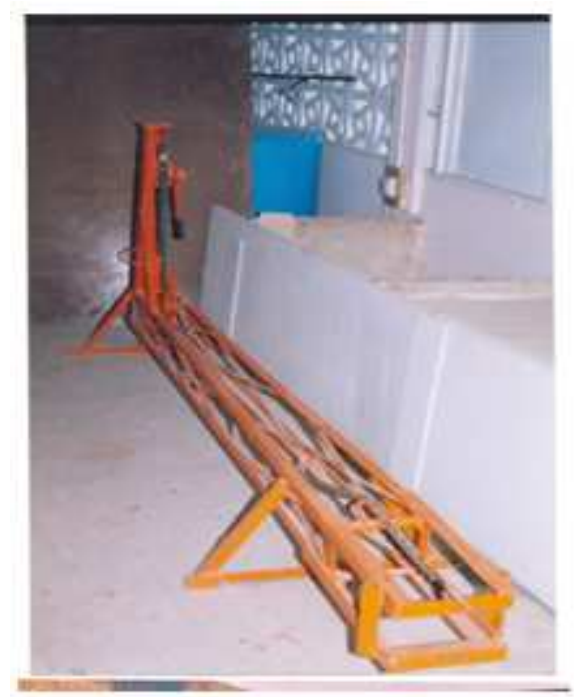

Figure 7. Puller system to pullout the shaft from the compacted clay mould

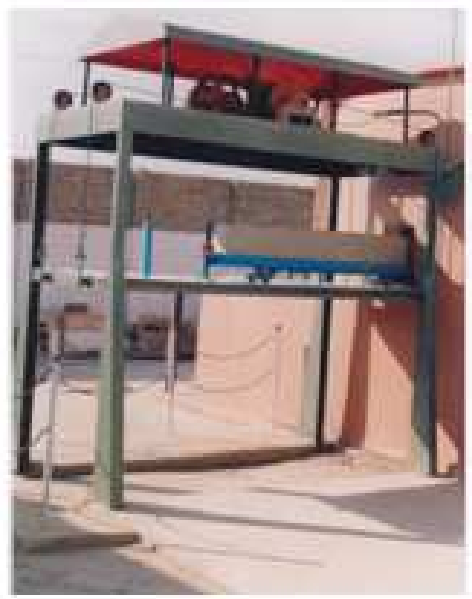

Figure 8. Platform Lift 


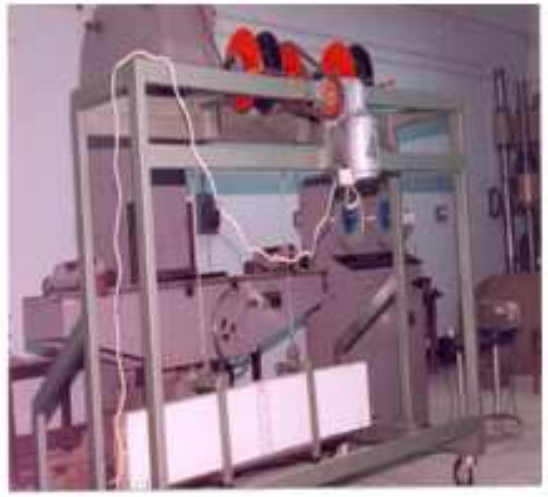

Figure 9. Mobile Lift

The bond between steel bars and the surrounding baked clay was achieved through forced grouting of cement slurry with fine aggregate in the ratio 1:1. After grouting, curing was done for 14 days. This created sufficient bond to avoid the problem of slipping of bars up to the ultimate load. The study was carried out in terms of modulus of rupture, shear/flexural behaviour, mode of failure, crack pattern and ultimate load.

Trolley was used for shifting the beams from place to place and platform lift as shown in Fig 8, used for lifting up of clay beams for placement in the kiln. Mobile Lift as shown in Fig 9, was used for carrying the beams to the testing laboratory for placement of these models on the Machine for testing. Torsee Testing Machine was used to test the beams. Load cells were used together with digital display system to measure intensity of the load independently.

Demec Gauge was used to measure the strain at various locations with reference to the neutral axis. Thirteen pairs of demec pads were stuck on the beam to measure the strain with the help of demec gauge. To test the fundamental structural properties of the beam material itself specimens were cut from the intact portions of beams after testing.

The flexural strength of all the beams in terms of steel and baked clay was estimated by using the recommendations of BS CP-8110[18] and ACI-318[19] after removal of partial safety factors. The shear strength was also estimated. After curing (shown in Fig 10) for 14 days the beam was allowed to dry completely for another 14 days.

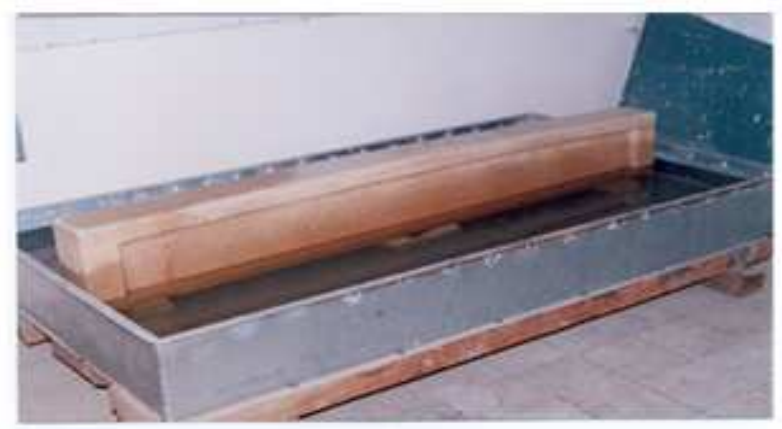

Figure 10. Curing Tub for curing thr baked clay specimens
The beams were finally tested by applying Uniformly Distributed Load, gradually in small increments. The strain was measured at the center throughout the depth at thirteen points. After every load increment each beam was checked carefully to detect cracks, if any.

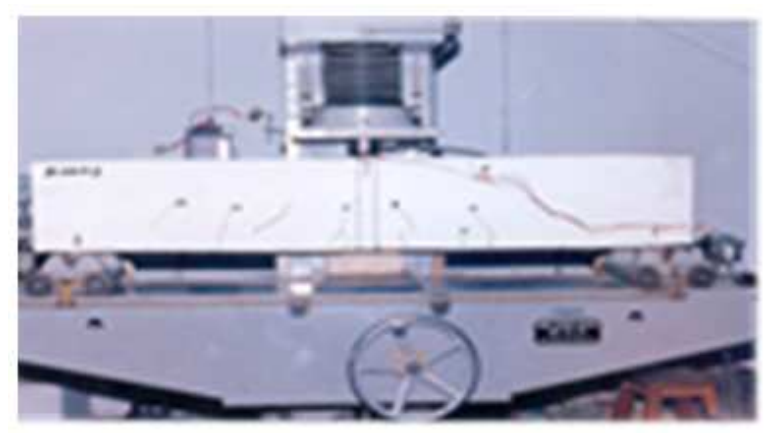

Figure 11. Baked Clay Rectangular beam tested by applying point load with roller supports.

The beams were tested by applying load with the help of Torsee Testing Machine as shown in Fig $11 \& 12$. The displacement at the centre of the beam was also noted.

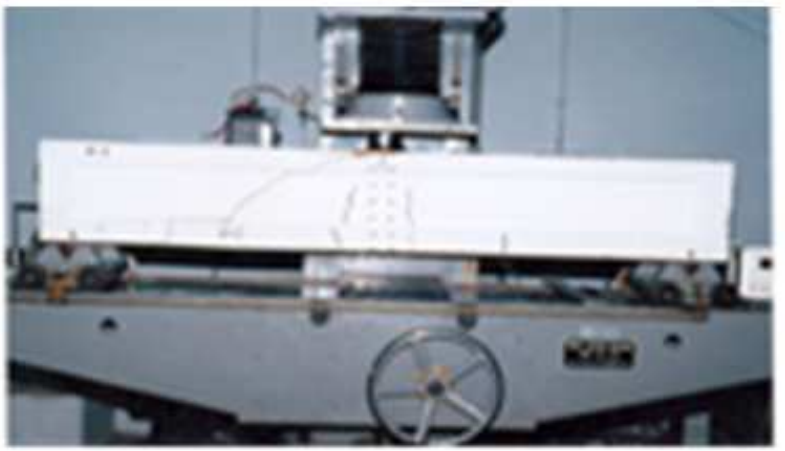

Figure 12. Baked Clay I-section beam tested by applying point load with roller supports.

\section{Present Investigations}

\subsection{Phase-I}

First phase consisted of twenty three beams, out of which fourteen were rectangular and nine were I-shaped. All were reinforced with two bars, thirteen by $9.8 \mathrm{~mm}$ (3/8 inch) diameter and ten with $12.7 \mathrm{~mm}(1 / 2$ inch) diameters bars. Nineteen beams were simply supported while four were plate supported at the time of testing. Fourteen beams were tested by applying point load at the centre and nine beams were tested by applying UDL (Uniformly Distributed Load) over a length of $1170 \mathrm{~mm}$ (46 inch).This scheme of loading was specially adopted to avoid any direct transfer of the load to the supports without inducing shear or flexural stress in the beams. The beams were compacted by applying a compression of $3.5 \mathrm{~N} / \mathrm{mm}^{2}$

During first phase the beam panels were fired for a total period of 19 hours. In few cases after testing the beams, it was observed that the inner core of about one inch thickness 
was not properly baked. Therefore, for the remaining phase of this experimental study the firing period was increased to 22 hours. Thus the problem was overcome. The firing temperature for initial six hours was only $250{ }^{\circ} \mathrm{C}$ in order to dry the water of hydration, which was raised to $950{ }^{\circ} \mathrm{C}$ for the remaining duration.

\subsection{Phase-II}

This $2^{\text {nd }}$ phase consists 6 beams which were cast, baked, post-reinforced, grouted and tested. The major parameter was the increase of external compressive force for compaction applied on freshly molded clay beams. The external compressive force applied on freshly cast beams for compaction was increased to $4.73 \mathrm{~N} / \mathrm{mm}^{2}$ from $3.5 \mathrm{~N} / \mathrm{mm}^{2}$. The slow increase of compression force is tried only to find the optimum/ acceptable limit of force which can economically be applied for a reasonable level of compaction. These beams were also simply supported. Two more beams were tested by supporting them on steel plates. In this also Uniformly Distributed Load was applied.

The beams showed an increase of ultimate load of 12 and $11 \%$ respectively for point load and for Uniformly Distributed Load, with simply supports and plate supports. When the beams were supported on steel plate the increase was only 0.5 percent. When the cubes were cut from the beams themselves after testing, the average crushing strength was found to be $36.52 \mathrm{~N} / \mathrm{mm}^{2}$ (5295 psi) as compared with the average value of $29.8 \mathrm{~N} / \mathrm{mm}^{2}$ (4321 psi). This may be compared with ordinary Port-land cement concrete used for buildings having characteristic strength of $20 \mathrm{~N} / \mathrm{mm}^{2}$ (3000 psi).

\subsection{Phase-III}

The purpose of testing beams of phase III of Main Test Series was to check the behaviour of baked clay beams with top steel and vertical steel. A compressive force of 4.75 $\mathrm{N} / \mathrm{mm}^{2}$ (690 psi) was applied for compaction. Two beams were reinforced with horizontal steel only while another two beams were reinforced with horizontal as well as vertical steel. In here behaviour of beams of baked clay with both top and bottom reinforcement as well as vertical steel bars as shear reinforcement have been included. All the four beams contained top and bottom steel and only two contained additional vertical steel consisting of $3 / 8$ inch diameter bars at 6 inch centre to centre.

\subsection{Phase-IV}

In continuation with the work that has been done regarding suitability of replacement of concrete, more beams have been tested containing double longitudinal reinforcement as well as vertical reinforcement to emulate the real structural actions which occur in the buildings. As per the plastic theory of bending, the bending moment re-distributes so that instead of $\mathrm{WL}^{2} / 24$ at centre changes to $\mathrm{WL}^{2} / 16$. Similarly $\mathrm{WL}^{2} / 12$ at the supports also changes to $\mathrm{WL}^{2} / 16$. Thus mechanism from giving three parts of hinges and failure occurs beyond that. In-order to investigate these points particularly regarding the behaviour of baked clay these beams were tested.

\subsection{Phase-V}

Baked clay beams the details of which are presented in this section were tested to study the behaviour of this particular material as a replacement of reinforced cement concrete. In fact in the advanced stage the idea emanated to apply a certain intensity of compression on beam panels so that their shear strength could be improved without inserting the shear reinforcement. Altogether eight beams were tested for this purpose and the results have been compared with previous research results to determine the viability of this particular idea. Although the actual ultimate conditions could not be reached due to immature failure of the end connections anchorage system consisting of nuts and welding on threaded steel bars which were used to reinforce and apply pre-compression to the baked clay. However, from the results it appears that if the anchorage is to be properly designed and strengthened the system would definitely work and positive results could be achieved.

\subsection{Concrete Beams}

A mix design of concrete grade-20 was prepared and beams were cast, one with tensile steel at bottom only and was tested by applying UDL (Uniformly Distributed Load). This beam was simply supported during testing. Two beams were reinforced both at top and bottom and were tested by applying UDL. One was simply supported and other was fixed end. The fourth beam was also doubly reinforced and was tested by applying UDL. This beam was fixed at both ends at the time of testing. The reinforcement consisted of two bars of $12.7 \mathrm{~mm}$ (1/2 inch) diameter everywhere. Three cubes and three cylinder were also cast at the time of casting the beams. Cubical strength, Modulus of elasticity as well as Poisson's ratio were determined on the day when beams were tested.

Depending upon the boundary conditions, estimated flexural strength in terms of steel and concrete together with two estimations on the basis of BS CP-8110[18] and ACI-318[19], results are presented in Table 1. It is apparent that the difference is only of the order of 0.6 to $10 \%, 0.4$ to $9.9 \%, 3.9$ to $8.4 \%$ and to 2.8 to $13 \%$ finally 10.2 to $11.4 \%$. This all can be regarded as negligible. Therefore, it can safely be concluded that baked clay is equally good if not better than concrete.

The percentage difference of experimental displacement of concrete is somewhat higher than that of baked clay. Averagely the displacement of concrete beam is $27 \%$ higher than the baked clay as shown in Table 2. Therefore it can safely be deduced that lesser the displacement, lesser shall be the cracking and ultimately behaviour of baked clay could be regarded as more favourable than concrete. Results are satisfactory and we are to find that baked clay is not an inferior material than concrete. 
Table 1. Comparative strength analysis of baked clay and concrete

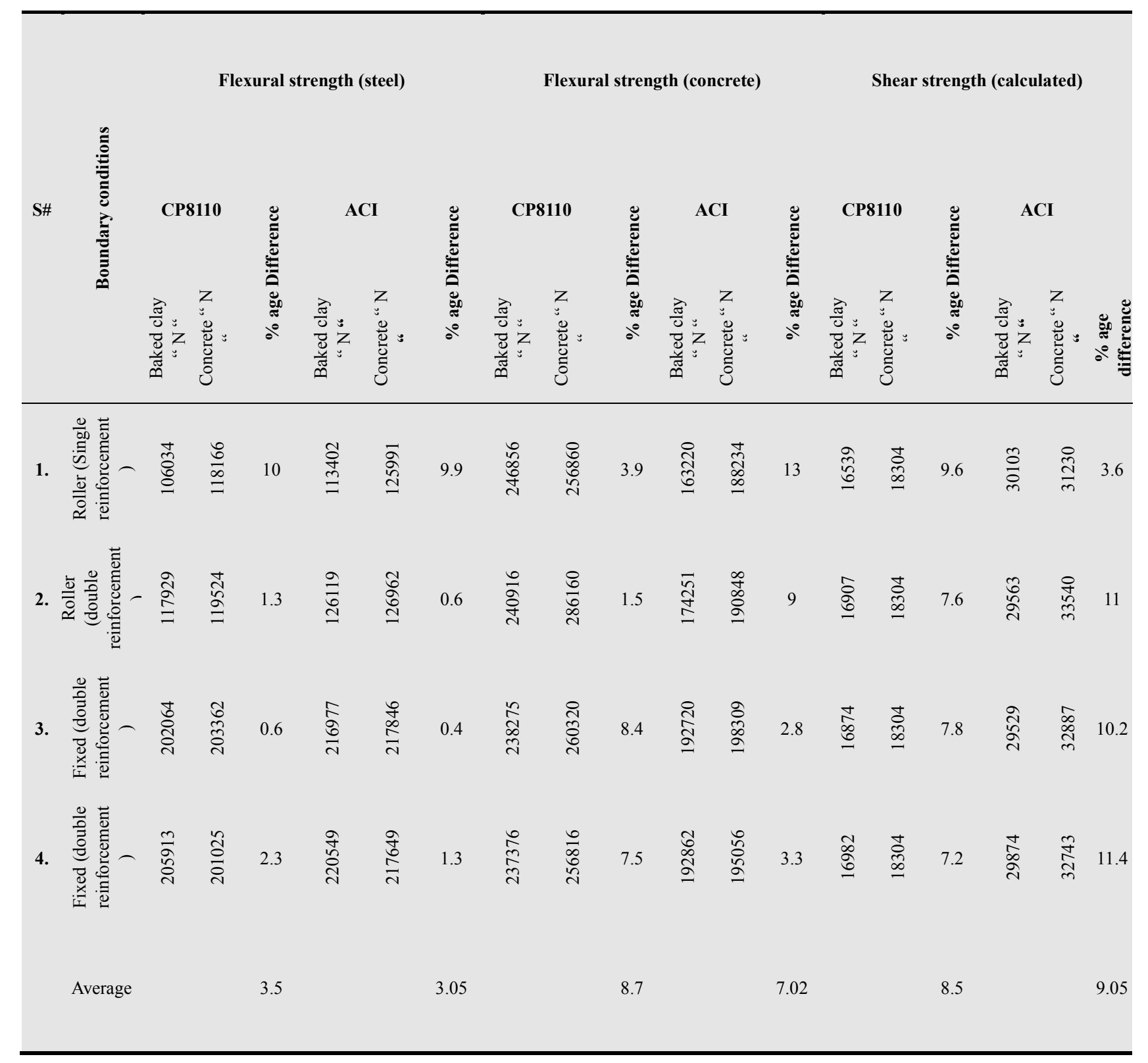

Table 2 Comparison of elastic and experimental displacement in concrete and baked clay beam.

\begin{tabular}{|c|c|c|c|c|c|c|c|c|}
\hline \multirow{2}{*}{ S\# } & \multirow{2}{*}{ Boundary condition } & \multirow{2}{*}{ Type of loading } & \multicolumn{3}{|c|}{ Elastic displacement calculated } & \multicolumn{3}{|c|}{$\begin{array}{c}\text { Experimental displacement at } \\
\text { ultimate load }\end{array}$} \\
\hline & & & Baked clay & Concrete & \%age diff: & Baked clay & Concrete & \%age diff: \\
\hline 1. & Roller (Single reinforced) & UDL & 0.78 & 1.07 & 27 & 8.81 & 11.30 & 22 \\
\hline 2. & Roller (Double reinforced) & UDL & 1.03 & 1.34 & 23 & 12.18 & 15.01 & 18 \\
\hline 3. & Fixed (Double reinforced) & UDL & 0.76 & 1.37 & 44 & 11.11 & 18.93 & 41 \\
\hline & Average & & & & $31.3 \%$ & & & $27 \%$ \\
\hline
\end{tabular}


Table 3. Comparison of experimental ultimate shear stress in concrete and baked clay beams.

\begin{tabular}{|c|c|c|c|c|}
\hline \multirow[b]{2}{*}{ S\# } & \multirow[b]{2}{*}{ Boundary condition } & \multicolumn{2}{|c|}{ Experimental ultimate shear stress } & \multirow[b]{2}{*}{$\%$ age difference } \\
\hline & & $\begin{array}{c}\text { Baked clay beam } \\
\mathrm{N} / \mathrm{mm}^{2}\end{array}$ & $\begin{array}{c}\text { Concrete beam } \\
\qquad / \mathrm{mm}^{2}\end{array}$ & \\
\hline 1. & Roller support (singly reinforced) & 4.3 & 4.5 & 4.4 \\
\hline 2. & Roller support (doubly reinforced) & 4.57 & 4.73 & 3.38 \\
\hline \multirow[t]{2}{*}{3.} & Fixed support (doubly reinforced) & 5.11 & 5.27 & 3.03 \\
\hline & & & Average & $3.6 \%$ \\
\hline
\end{tabular}

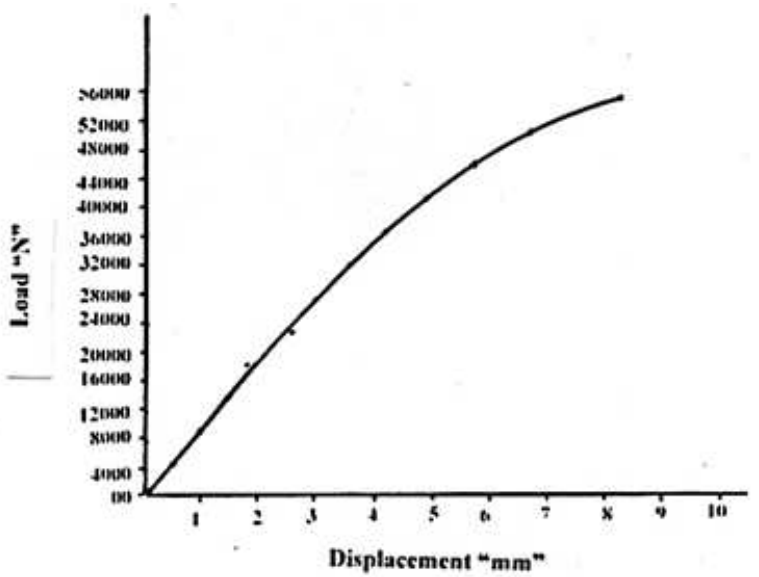

Figure 13. Graph showing load-displacement relationship of the baked clay beam.

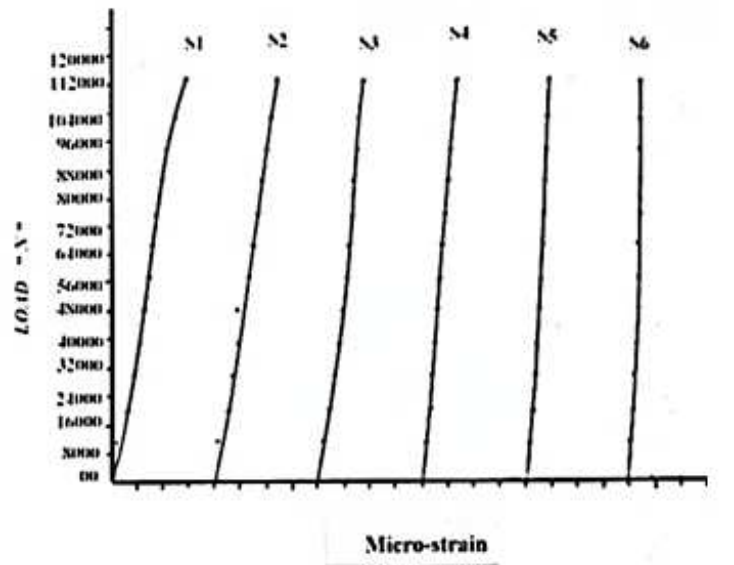

Figure 14. Graph showing load-strain relationship of baked clay beam.

Looking at Table 3, which compares the potential factor of safety of baked clay and concrete it is evident that there is a slight difference of only $3.6 \%$ between the two which could be ignored and therefore baked clay is equally strong enough to replace concrete.

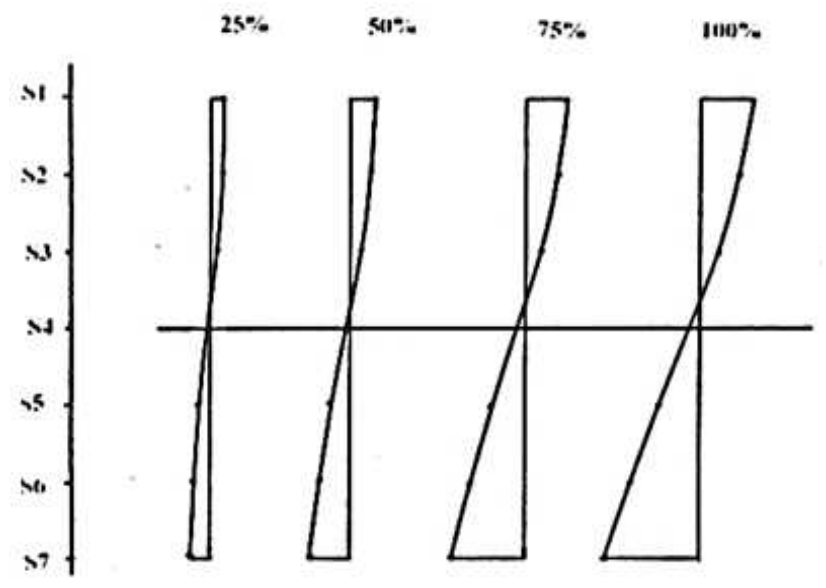

Figure 15. Graph showing variation of strain with depth of baked clay beam

This scheme of testing was particularly aimed at finding the difference between the structural behaviour of concrete and the baked clay. It was particularly a system where we could know whether the baked clay could be used as structural material like concrete. It could be deduced that baked clay if not superior, could match RCC.

Beams which were tested, only 1.95 meters long. However, in real structures beams could be very long and more commonly loads are distributed because slab transfers the load to the beam along its entire span. The structure produced with panels of pre-perforated post-reinforced baked clay shall exhibit even better performance. The load-displacement relationship, the strain in baked clay at the centre in its extreme fibre and the variation of strain throughout the depth of the beams at $25 \%, 50 \%, 75 \%$ and one stage before ultimate load are presented in Fig. 13 to 15

From the figures it can be observed that the failure occur when the load displacement relationship was not in the ultimate stage . Otherwise the bond between steel and baked clay was perfect. The failure was sudden and brittle without prior warning indicating that it was dominated by shear. Full flexural strength was not reached. 


\section{Conclusions}

Based on test results the following conclusions have been arrived at:

(1) An idea of using the most natural material i.e. clay requires no industrial processing except baking which is an established form of processing clay.

(2) Buildings must be erected cheaply but for a sufficiently long life and for generations to use them. But the cost must be within the reach of common man.

(3) The future of the Off-spring must not be mortgaged for a roof over their heads.

(4) The major aim of this research is to make it possible in the plane of Pakistan for every rich and poor to afford a home of his own, which may resist the rigors of climate, environment and catastrophes must not cause a hazard to at least the occupants.

(5) The human generation shall be best served if clay is used for roof over their heads.

(6) It was observed that best results could be achieved when the clay is $70 \%$ and Pit sand $30 \%$.

(7) When cubes of $100 \mathrm{~mm}$ size were cast after applying a compacting force of $6 \mathrm{~N} / \mathrm{mm}^{2}$ and baked, average cubical strength as high as $27.61 \mathrm{~N} / \mathrm{mm} 2$ was achieved for 70 percent clay together with 30 percent pit-sand.

(8) When cubes and cylinders were cut from the body of the beams themselves after testing the Poisson's ratio was found to be 0.173 as compared with that of concrete which ranges between 0.15 to 0.21 .

(9) The average value of modulus of elasticity for all tested beams was found to be $33.7 \mathrm{KN} / \mathrm{mm} 2$ as compared with $25 \mathrm{KN} / \mathrm{mm} 2$ for concrete of grade-20.

(10) Predominantly all the beams failed in shear and full flexure strength was not achieved.

(11) Compactive force seems to have drastic effect on the properties like specific gravity and shrinkage of baked clay specimens. Specific gravity as high as 2.35 has been achieved when compacting force (compression) was $6 \mathrm{~N} / \mathrm{mm} 2$ for a $70 \%$ clay $+30 \%$ pit-sand.

(12) The average shrinkage for the specimens was $2 \%$ when the compacting force was zero. However, it reduced to $1 \%$ when compacting force was 6 $\mathrm{N} / \mathrm{mm}^{2}$.

(13) The specific weight of baked clay with a compacting force of $6 \mathrm{~N} / \mathrm{mm}^{2}$ was found to be $22.36 \mathrm{kN} / \mathrm{m}^{3}$ as compared with $24 \mathrm{kN} / \mathrm{m}^{3}$ for ordinary concrete.

(14) The average value of modulus of elasticity for all tested beams was found to be $33.7 \mathrm{KN} / \mathrm{mm}^{2}$ as compared with $25 \mathrm{KN} / \mathrm{mm} 2$ for concrete of grade-20.

(15) Cubical strength as high as $37.4 \mathrm{~N} / \mathrm{mm}^{2}$ was reached when cube were cut from the beam cost with a compacting force of $4.75 \mathrm{~N} / \mathrm{mm}^{2}$. An average value was found to be $33.52 \mathrm{~N} / \mathrm{mm}^{2}$.

(16) It is quite apparent that the failure of beams is dominated by shear rather than flexure, therefore, shear strength must be improved to ensure ductile failure due to yielding of steel in tensile zone.

(17) Split of bottom cover, slipping of bars or destruction of bond between steel and surrounding material did not take place, showing that the system of grouting worked well and was adequate.

(18) The presence of vertical steel bars as shear reinforcement did not show any improvement of strength rather it acted as an intruder.

(19) Presence of longitudinal steel in compression zone proved to be beneficial causing substantial improvement of shear strength.

(20) Beams subjected to Uniformly Distributed Load and fixed at both ends showed a very good strength which is averagely 5 times more than the calculated strength when estimated by using CP8110 recommendation for beams containing top and bottom steel without but no vertical steel. Whereas it is 2.91 times when compared to the calculated value by using ACI-318.

(21) Pre-perforated post-reinforced system of construction consisting of pre-cast panels of baked clay holds promise as an alternative of cement concrete at a reduced cost without compromising on the quality, durability and elegance of multistory buildings.

\section{Acknowledgements}

Experimental study the details of which are presented in this paper was carried out in the Structures Laboratory of the Department of Civil Engineering at Quaid-e-Awam University of Engineering science \& Technology, Nawabshah, (Sindh), Pakistan.

\section{References}

[1] Ansari.A.A. \& Memon M, (1999), "Preliminary study of Structural properties of baked clay" Mehran University Research Journal of Engineering \& Technology, jamshoro, Vol. 18, No.3, July 1999, pp. 161-166

[2] Ansari. A.A., (2006), "Fundamental Structural Properties of Compacted baked Clay Specimens", Quaid-e-Awam University Research journal of Engineering, science \& Technology, Nawabshah. Vol. 7, No. 2, pp.39-44, July-Dec

[3] Ansari. A.A., (2007), "Clay : The Environment Friendly Material of Construction", Proceedings first National Conference on Assessment and Proper Utilization of Indigenous Energy Resourses and their Impact on Energy, Organized by Energy and Environment Energy Department, Quaid-e-awam University of Engineering Science \& Technology, Nawabshah. Pakistan, 26-28 Feb 2007.

[4] Ansari. A.A., (2007)“ Behavior of baked clay Structural beam panels", Proceeding Ninth International Summer 
Symposium, Yokohama National University, Yotsuya 1-chome, Shinjuku-ku, Tokyo, 160-0004, Japan, organized by Japan Society of Civil Engineers, (JSCE), japan, 18th September 2007.

[5] Ansari A.A., (2007), "Mechanical System Developed for Reinforced baked Clay Structural Panels", Proceeding International Conference of failure of Engineering Materials \& Structures FEMS (22-23 October 2007), Organized by Mechanical Engineering Department, University of Engineering \& Technology, Texila. Pakistan.

[6] Ansari. A.A., (2007), "Use of RBC New material of Construction for Multistory Buildings", Proceeding 5th Civil Engineering Congress, Organized by the Institute of Engineers Pakistan , Karachi, Pakistan, 8th-9th Dec; 2007.

[7] Ansari A.A \& Memon M., (2007), “ Pre-Perforated Post-Reinforced Baked Clay Structural Panels for Low-Cost Construction Option" Proceeding International Workshop on Cement Based Materials \& Civil Infrastructure, Organized by ACI Pakistan Chapter, held on 10th-11th December 2007 at pearl Continental Hotel, Karachi. Pakistan.

[8] Ansari, A.A., (2008), "RBC as Low-Cost Alternative of RCC as Structural Material" Proceeding NC-PTD-2008, national Conference on Phase Transformations and Deformation in Engineering Materials, organized by Institute of Advanced Materias, Bahauddin Zakaria University, Multan, Pakistan, held on February 8-9, 2008.

[9] Ansari A.A., (2008), “ Management Aspects of Building Construction Using RBC", Proceeding Ist International Conference on Engineering Management, benchmarking Management Practice in Developing Countries, ICEM-2008, Organized by Department of Civil Engineering, Mehran University of Engineering \& technology, Jamshoro, Pakistan, held on 4-5 March 2008.

[10] Ansari A.A., (2008), "A New Approach to Construction of Building Using RBC as Ecological Superior Material", Proceeding Second National Conference on Energy and Environment Issues, Concerns and Options, Organized by Energy and Environment Engineering Department, Quaid-e-Awam University of Engineering Science \& Technology, Nawabshah, Pakistan, 27-29, March 2008.
[11] Ansari. A.A., (2009), "Clay; the Universal Accommodator of Humanity", proceeding Eleventh International Summer Symposium , Tokyo Institute of technology, Tokyo, Organized by Japan Society of Civil Engineers, (JSCE), japan, 11th September 2009.

[12] Ansari. A.A. (2009), Baked clay as replacement of reinforced Concrete", proceeding Second Official Regional Conference of international institute for FRP in Construction (IIFC) for Asia Pecific Region, organized by Department of civil Engineering, Hanyang University, Soul, koria 9th-11th, December 2009.

[13] Ansari A.A, Memon. M \& Khaskheli G.B., (2011), "Pre-Perforated Post-Reinforced Structural Panels of baked Clay as Cheaper Alternative, Paper presented in 12th East Aasia Pacific Conference on structures Engineering and Construction (EASEC), Hongkong, \& published in the Procedia Engineering 14(2011), 2635-2641, on line: www.scencedirect.com, 1877-7058, 2011 published by Elsevier Ltd, doi; 10.1016/j proeng 2011.07.391

[14] Ansari. A.A., (2011), "Performanceof post-Reinforce baked clay Panels of beams", proceeding 3rd CUTSE 2011, International Conference held in Miri, Sarawak, Malasia, 8-9 November, 2011.

[15] Ansari A.A. \& Lakho. N.A., (2013), "Determination of Structural Properties of Baked clay as Repalcement of RCC", International Journal of Emerging Technology \& Advanced Engineering, New Dehli, India. web site: www.ijetae.com(ISSN (2250-2459, ISO 9001,2008 certified journal) Vol. 3, Issue2, Feb 2013.

[16] Hendrik N., (1997), "Clay Materials for Self-Reliant Potter", pp. 1-31, Clay Science, Vol. 10, No. 3, pp. 1-31,

[17] Greyt. G. (1968), "Defination Clay", Greyt Gift Home, Premium soil stabilizers Global leader of soil stabilization, pp. 1-2, 1968..

[18] British Standard Institution, (1972), “CP-110, The Structural use of Concrete," Part-I, Design Materials and workmanship

[19] ACI-318, Building Code Requirement for Reinforced Concrete, American Concrete Institute. 